ISSN : $2407-0742$

\title{
AN ANALYSIS OF TECHNIQUES OF ADJUSTMENT IN TRANSLATING RELIGIOUS TEXT VOCABULARIES (A STUDY ON SERIES OF A HANDBOOK ON THE REVELATION TO JOHN)
}

\author{
Sujatmiko \\ Teacher Training and Education Faculty \\ PGRI University of Yogyakarta \\ sujatmiko_upy@yahoo.com
}

\begin{abstract}
This research is entitled "An Analysis of Techniques of Adjustment in Translating Religious Text Vocabularies (A Study on Series of A Handbook on the Revelation to John)'. It is about how religious text vocabularies are translated by using technique of adjustment. It is aimed to find types of techniques of adjustment and their subtypes.

This research uses qualitative method to analyze the data. Techniques of analyzing data in this research consist of 3 components; they are (1) reducing the data, (2) explaining the data, and (3) taking a conclusion. Reducing data is a process of selecting, focusing, simplifying and abstracting the data. Explaining the data is a process of organizing information and arranging the complete narration. Taking a conclusion is a process of drawing conclusion from the data. The data sources of this research are A Handbook on the Revelation to John and its Indonesian translation entitled Seri Pedoman Penafsiran Alkitab Wahyu Kepada Yohanes.

After conducting the research, the researcher finds 73 data. Alteration technique is in the first position with 55 data or $74.2 \%$. Then, addition technique is in the second position with 12 data or $16.4 \%$. The last is subtraction technique with 6 data or $8.2 \%$. Addition technique is divided into 3 classifications, i.e. obligatory specifications (3 data or 4.1\%), amplifications (7 data or 9.6\%), and classifiers (2 data or 2.7\%). Subtraction technique is divided into 2 classifications, i.e. conjunctions (3 data or $4.1 \%$ ) and formulae (3 data or $4.1 \%$ ). Alteration technique is divided into 7 classifications, i.e. sounds (15 data or 20.5\%), categories (6 data or $8.2 \%$ ), word classes (2 data or $2.7 \%$ ), order (6 data or $8.2 \%$ ), clause and sentence structure (1 datum or 1.4\%), semantic problems involving single word (19 data or 26\%), and semantic problems involving exocentric expression (6 data or $8.2 \%$ ).

This research is expected to open wide opportunities and challenges to academicians, 646333255especially those in translation linguistics sphere to deepen their research and study, especially in translating the holy religious texts in order to be a new contribution to the translation fields.
\end{abstract}

Keywords: technique of adjustment, religious text vocabularies, handbook on the revelation to John.

\section{Background of the study}

Translation is a complicated process. In this case, a translator has a big responsibility for transferring message from source language to target language. The form of target language may be different from the form of source language. However, target language has a way and style to express the same message as in source language.

Larson (1984:22) states clearly that translation is a complicated process. However, a translator who is concerned with transferring the meaning will find that the receptor language has a 
way into which the desired meaning can be expressed, even though it may be very different from the source language form.

Nida and Taber (1974:12) also has opinion that translating consists of reproducing in the receptor language the closest natural equivalent of the source language message, first in terms of meaning and secondly in terms of style. From this statement, it is known that a translator as a message receptor in the source language and when in the process of translation, he/she is a message sender in the target language.

In reproducing message from source into target language, undoubtedly there are some techniques which used to translate. Nida (1964:226), in his book Toward a Science of Translating provides three types of techniques of adjustment: additions, subtractions, and alterations.

Additions conducted to reproduce the message. It does not mean that a translator exaggerates the meaning. But, it purposes to add the information that may not be known by the people in target language. Accordingly, they can catch the message from source language. This matter is appropriate with Nida's statement (1964:226), "the translator's basic task is to reproduce what he has been given, not to improve it, even when he thinks he can do so".

Subtractions eliminate or reduce unnecessary repetition to avoid ambiguity. Though subtraction eliminates or reduces the word or phrase or even the entire text, it is expected do not eliminate or reduce the message. It makes target language will be more effective so the people in target language can get the message easily.

Alterations caused by incompatibilities between two languages (Molina and Albir, 2002:502). The incompatibilities occurred due to each language has its own rules. Accordingly, the entire text must be subjected to a series of changes, involving not only additions and subtractions, but also alterations (Nida, 1964:233). Alterations occurred from the simplest problems in sounds to the most complicated problems in idiomatic phrases.

In accordance with techniques of adjustment above, the researcher is interested in conducting an analysis to identify the types of techniques of adjustment and its subtypes which is found in $A$ Handbook on the Revelation to John and its Indonesian translation Pedoman Penafsiran Alkitab Wahyu kepada Yohanes. It becomes one of essential material prepared by IBS (Indonesian Bible Society) to help local translator in translating Bible to local languages. Translators have to translate text from source language to target language carefully because it is a religious text.

Translating religious text is a sensitive issue. From faith's perspective, religious text is believed and accepted as inscrutable and unchangeable Word of God which is supposed to be preserved in term of both forms and contents. From readers' point of view, however, there is a high need of reading and understanding the Word of God, which is written in foreign language, within their own mother tongue. From literature's standpoint, religious text has unique and complex characteristics. It is within these contexts, the role of translation is highly challenged. 
IBS uses 'adaptation' as a technical term to refer to translation process of SPPA (Seri Pedoman Penafsiran Alkitab). And hence, 'the adaptors' is used instead of translator. The term refers to the adaptors' functions and roles which are not only translating English texts into Indonesian language, but also interpreting, selecting, and doing contextualization processes to produce SPPA. In accordance with IBS, the researcher decided to use 'the adaptors' as a technical term instead of 'translator' in this research.

This research is aimed to identify the types of techniques of adjustment and its subtypes which used by the adaptors. The following are the examples of the types of techniques of adjustment which used to translate the data:

Example 1:

SL: Pergamum

\section{TL: Kota Pergamum}

The example above shows that the adaptors add the word 'kota' before 'Pergamum'. It is to clear that 'Pergamum' is a city.

Example 2:

\section{SL: To His God and Father}

TL: Bagi Allah, Bapa-Nya

The adaptors use subtractions technique to eliminate the word 'and'. They eliminate 'and' because between 'God' and 'Father' there is a link coordinate or relationship. They want to clarify that 'God' and 'Father' are not two persons but only one. Accordingly, the subtype is conjunctions. After analyzing the content of A Handbook on the Revelation to John, the researcher is interested in conducting an analysis of religious text vocabularies.

\section{Research Questions}

Considering to the background of the study, the research is conducted to answer the following questions:

1. What are the techniques of adjustment applied by the adaptors in translating vocabularies in $A$ Handbook on the Revelation to John?

2. What are the subtypes of each technique of adjustment applied by the adaptors in translating vocabularies in A Handbook on the Revelation to John?

\section{Research Objectives}

The objectives of this research are:

1. To identify the techniques of adjustment applied by the adaptors in translating vocabularies in $A$ Handbook on the Revelation to John.

2. To identify the classifications of each technique of adjustment applied by the adaptors in translating vocabularies in A Handbook on the Revelation to John. 


\section{Research Significance}

This research is expected to give contributions to translation studies such as the followings:

1. To solve translating Bible's problem, mainly related to language adaptation for local translator.

2. To give advises in developing and improving the Bible understands efforts in accordance with the education level and the society of special culture.

3. To complete the relevant research's results as a new contribution for applied linguistic major in translation studies.

\section{Literature Review}

There are some definitions of translation delivered by some experts. The definition comes from Catford in Suryawinata and Hariyanto, 2003:11. He says that translation is the replacement of textual material in one language by equivalent textual material in another language. He adds the explanation that textual material is not always in written but also in oral form.

Another opinion is from Savory (ibid: 12), translation is made possible by an equivalent of thought that lies behind its different verbal expression. From his statement, it is stated that the equivalent is an idea. He does not explain about the process. Further, Pinhuck (ibid: 13) also has opinion about translation. According to him, translation is a process of finding a TL equivalent for an SL utterance.

In the definition, Nida and Taber (1982:12) state clearly about the process. Their statement is translating consists of reproducing in the receptor language the closest natural equivalent of the source language message, first in terms of meaning and secondly in terms of style. From this statement, they state that translating is not only replace source language into target language, but also concern in meaning and language style.

These Bible translators also say that the best translation does not like a translation, because translating must aim primarily at reproducing the message. But to reproduce the message, one must make a good grammatical and lexical adjustment. For example, the phrase 'Good Friday' in Christian term cannot be translated into 'Hari Jumat yang baik' in Indonesia. Translator has to catch the real message of this phrase. A meaningful equivalent is 'Jumat Agung', a day of Christ's crucifixion.

Newmark (in Suryawinata \& Haryanto, 2003:15) also has an opinion about translation. It is a craft consisting in the attempt to replace a written message and/or statement in one language by the same message and/or statement in another language. He gives a limitation that translation involves written message and/or statement. It is to differentiate between translation and interpretation.

Nida (1964:226-238), in his book Toward a Science of Translating states there are three kinds of techniques: additions, subtractions, and alterations. The purposes of these techniques are used: 1) to adjust the form of the message to the characteristics of the structure of the target language; 2) to produce semantically equivalent structures; 3 ) to generate appropriate stylistic equivalences; 4) to produce an equivalent communicative effect. Those techniques have subtypes of technique. 
Nida (1964:227-230) divides nine types of additions translation technique, they are: filling out elliptical expressions, obligatory specification, additions required by grammatical restructuring, amplification from implicit to explicit status, answers to rhetorical questions, classifiers, connectives, categories, and doublets.

Subtractions eliminate or reduce unnecessary repetition to avoid ambiguity. Though subtraction eliminates or reduces the word or phrase or even the entire text, it expected do not eliminate or reduce the message. It makes target language will be more effective so the people in target language can get the message easily. Nida lists seven situations where the translator should use this technique: repetition, specification of reference, conjunctions, transitional, categories, vocatives, and formulae.

Alterations come from the simplest problem of correspondence in sounds to the most complicated adjustment in idiomatic phrases (Nida, 1964:233). It is because the changes occur in the form of sound until the semantic problems. In general, alterations can be divided into the following classes: sounds, categories, word classes, order of elements, clause and sentence structures, semantic problems involving single words, and semantics problems involving exocentric expressions.

\section{Research Method}

This research was conducted by applying descriptive qualitative method. The characteristic of this method provided the result of the research in the form of detail sentence description, complete and deep explanation of the process of why and how did something happen (Sutopo, 2006:135-139). The use of descriptive qualitative method in this research was aimed at describing types and its subtypes of techniques of adjustment applied by the adaptors in translating religious text vocabularies.

\section{Data Source}

The objects in this research were A Handbook on the Revelation to John published by United Bible Societies (UBS) New York and its Indonesian translation entitled Seri Pedoman Penafsiran Alkitab Wahyu Kepada Yohanes published by Indonesian Bible Society (IBS) Jakarta. The analysis focused on vocabularies; either it was a word or phrase.

\section{Techniques of Data Collections}

The research based on information in recording; either it was picture, voice, or text, usually called document analysis or content analysis (Arikunto, 2009:244). In addition, Creswell (2003:185188) stated that there were four basic procedures in collecting the data, they were observations, interviews, collecting documents, and audio and visual material.

In this research, the researcher collected documents in collecting the data. Collecting document was conducted by comparing source and target language to look for the types of techniques of adjustment and its subtypes. To collect the data, the researcher used some steps, they were:

1. The researcher read A Handbook on the Revelation to John and its Indonesian translation.

2. The researcher tried to find the data by comparing source and target language. 
3. To simplify in comparing source and target language in this research, the researcher drew table as below:

\begin{tabular}{|c|c|c|c|c|}
\hline No. & SL & TL & $\begin{array}{c}\text { Types of } \\
\text { Techniques of } \\
\text { Adjustment }\end{array}$ & $\begin{array}{c}\text { Subtypes of } \\
\text { Techniques of } \\
\text { Adjustment }\end{array}$ \\
\hline & & & & \\
\hline & & & & \\
\hline
\end{tabular}

In collecting the data, the researcher classified them into each subtypes. Then the data put into its code. The examples of the code were:

1. 01/SL/TL/A.01/Add/FEE

2. 01/SL/TL/B.01/Add/OS

3. 01/SL/TL/C.01/Add/Ampli

4. 01/SL/TL/D.01/Add/Class

5. 01/SL/TL/E.01/Add/CRL

6. 02/SL/TL/A.01/Sub/Conj

7. $02 / \mathrm{SL} / \mathrm{TL} / \mathrm{B} .01 / \mathrm{Sub} / \mathrm{Ctgrs}$

8. $02 / \mathrm{SL} / \mathrm{TL} / \mathrm{C} .01 / \mathrm{Sub} /$ For

9. 03/SL/TL/A.01/Alt/Sou

10.03/SL/TL/B.01/Alt/Ctgrs

11.03/SL/TL/C.01/Alt/WC

12.03/SL/TL/D.01/Alt/Ord

13.03/SL/TL/E.01/Alt/CSS

14.03/SL/TL/F.01/Alt/SPISW

15.03/SL/TL/G.01/Alt/SPIEE

Note:

1 : first type of techniques of adjustment (Addition)

2 : second type of techniques of adjustment (Subtractions)

3 : third type of techniques of adjustment (Alterations)

SL : Source Language

TL : Target Language

A.01 : the number of data

Add : Addition

FEE : Filling out elliptical expression

OS : Obligatory specification

Ampli : Amplification 


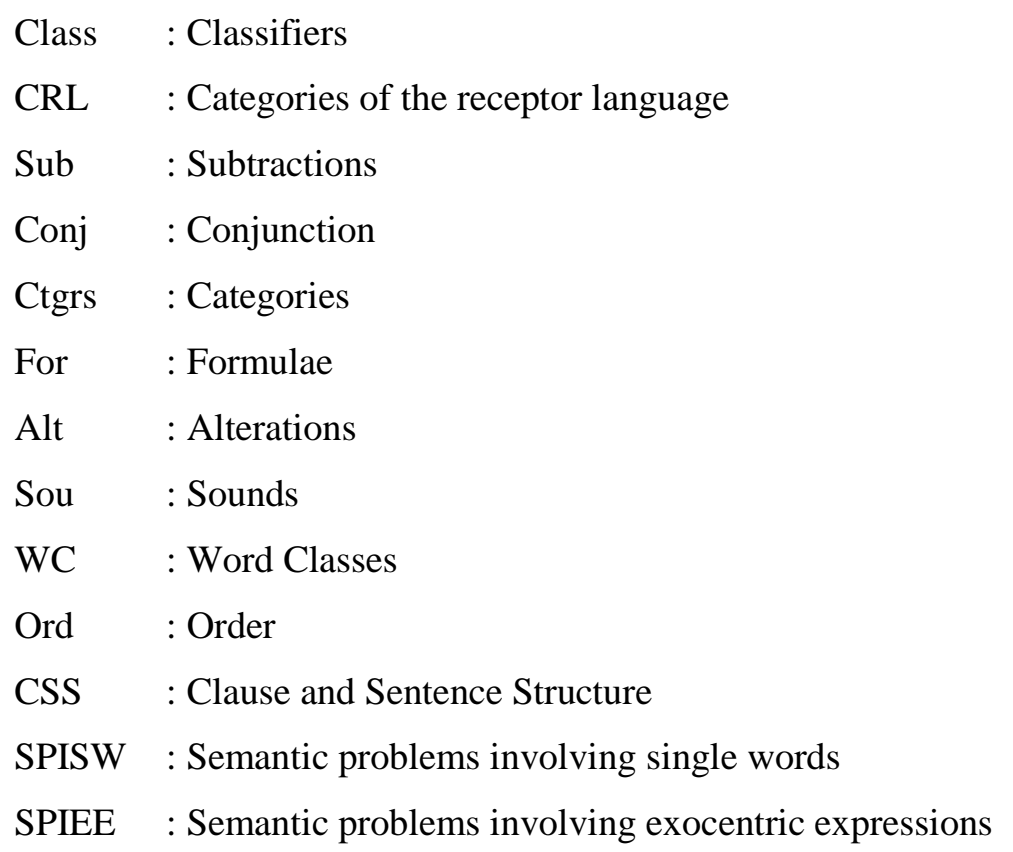

\section{Techniques of Data Analysis}

Techniques of analyzing data in this research consist of 3 components; they were (1) reducing the data, (2) explaining the data, and (3) taking a conclusion (Miles and Huberman in Sutopo, 2006:113-116).

Reducing data was a process of selecting, focusing, simplifying and abstracting the data. Explaining the data was a process of organizing information and arranging the complete narration, therefore, it enabled to draw a conclusion. Taking a conclusion was a process of drawing conclusion from the data.

The researcher used some steps to analyze the data, they were:

1. The researcher identified the data by comparing source and target language to determine the types of techniques of adjustment using Nida's theory.

2. Then, the researcher classified each data by grouping them in each type of techniques of adjustment.

3. Next, the researcher explained each data about what the technique was used.

4. The last was the researcher drew a conclusion of the analysis result.

\section{Result and Discussion}

The researcher finds 73 data. Alteration technique is in the first position because it is mostly used by the adaptors with 55 data or $74.2 \%$. Then, addition technique is in the second position with 12 data or $16.4 \%$. The last is subtraction technique with 6 data or $8.2 \%$.

Addition technique is divided into 3 types, i.e. obligatory specifications (3 data), amplifications ( 7 data), and classifiers (2 data). Subtraction technique is divided into 2 types, i.e. 
conjunctions ( 3 data), and formulae ( 3 data). Alteration technique is divided into 7 types, i.e. sounds (15 data), categories (6 data), word classes ( 2 data), order (6 data), clause and sentence structure (1 datum), semantic problems involving single word (19 data), and semantic problems involving exocentric expression ( 6 data).

The types of techniques of adjustment and their subtypes and the total data of this research are explained in the following table:

Table 1: Classification of the data

\begin{tabular}{|c|c|c|c|c|}
\hline No. & $\begin{array}{l}\text { Techniques } \\
\text { Adjustment }\end{array}$ & $\begin{array}{l}\text { Subtypes of techniques of } \\
\text { adjustment }\end{array}$ & Total & $\%$ \\
\hline 1. & Additions & $\begin{array}{l}\text { Obligatory specification } \\
\text { Amplification } \\
\text { Classifiers }\end{array}$ & $\begin{array}{l}3 \\
7 \\
2\end{array}$ & $\begin{array}{l}4.1 \\
9.6 \\
2.7\end{array}$ \\
\hline \multicolumn{3}{|r|}{ Total } & 12 & 16.4 \\
\hline 2. & Subtractions & $\begin{array}{l}\text { Conjunctions } \\
\text { Formulae }\end{array}$ & $\begin{array}{l}3 \\
3\end{array}$ & $\begin{array}{l}4.1 \\
4.1\end{array}$ \\
\hline \multicolumn{3}{|r|}{ Total } & 6 & 8.2 \\
\hline 3. & Alterations & $\begin{array}{ll}\text { Sounds } & \\
\text { Categories } & \\
\text { Word Classes } & \\
\text { Order } & \\
\text { Clause and } & \text { sentence } \\
\text { structure } & \\
\text { Semantic } & \text { problems } \\
\text { involving single } & \text { words } \\
\text { Semantic } & \text { problems } \\
\text { involving } & \text { exocentric } \\
\text { expressions } & \\
\end{array}$ & $\begin{array}{l}15 \\
6 \\
2 \\
6 \\
1 \\
19 \\
6\end{array}$ & $\begin{array}{l}20.5 \\
8.2 \\
2.7 \\
8.2 \\
1.4 \\
26 \\
8.2\end{array}$ \\
\hline \multicolumn{3}{|r|}{ Total } & 55 & 74.2 \\
\hline & & Total data: $12+6+55=$ & 73 & $98.8 \%=100 \%$ \\
\hline
\end{tabular}

\section{Discussion}

The researcher finds 12 data of additions techniques that are categorized into 3 subtypes. They are obligatory specification, amplification, and classifiers.

\section{Obligatory specification}

The specification is required in some translations to avoid an ambiguity in the receptor language formation and to avoid misleading reference. There are 3 data which use these techniques.

\section{Datum 01/SL/TL/A.01/Add/OS}

SL: Asia (p.18)

TL: Asia Kecil (p.16)

The word 'Asia' is adapted into 'Asia Kecil'. There is an addition the word 'Kecil'. It is conducted by the adaptors to clarify that Asia Kecil was the Roman province in what is now southwestern Turkey. It is different from 'Asia' today. 


\section{Datum 01/SL/TL/A.02/Add/OS}

SL: I John, your brother (p.26)

TL: Aku, Yohanes, saudara dan sekutumu (p.24)

From the datum above, there is an addition of the word 'sekutumu'. It is to explain that 'Yohanes' is not only a brother but also a partner of the people who receive the letter from him. They are Christian people who believe and faith in Jesus Christ. Therefore, the adaptors add the word 'sekutumu'.

The other data which use this technique are as follow:

Table 2: Obligatory specification

\begin{tabular}{|l|c|}
\hline No & Code \\
\hline & $01 /$ SL/TL/A.01/Add/OS \\
\hline & $01 /$ SL/TL/A.02/Add/OS \\
\hline & $01 /$ SL/TL/A.03/Add/OS \\
\hline
\end{tabular}

\section{Amplification}

This technique shows detailed message explicitly or paraphrases implicit information from source language into target language. Translations which use amplification technique can be seen in the data below:

\section{Datum 01/SL/TL/B.01/Add/Ampli}

SL: Clothed with a long robe (p.30)

TL: Jubah yang panjangnya sampai di kaki (p.27)

In this datum, there is an addition of information. The adaptors explain that 'robe' is a long dress covering the feet. It purposes to give detailed message of the word 'robe'

\section{Datum 01/SL/TL/B.05/Add/Ampli}

SL: the sun shall not strike them. (p.131)

TL: matahari atau panas terik tidak akan menimpa mereka lagi. (p.130)

There is an addition in the data above. The adaptors add another equivalent phrase to translate 'the sun'. It purposes to avoid ambiguity about not 'the sun' will strike them but the piercing heat of sun will strike them. Therefore, the adaptors add the phrase 'panas terik'.

The $7^{\text {th }}$ data which use amplification technique with the code as follows: 


\section{Table 3: Amplification}

\begin{tabular}{|l|c|}
\hline No & Code \\
\hline & $01 / \mathrm{SL} / \mathrm{TL} / \mathrm{B} .01 /$ Add/Ampli \\
\hline & $01 / \mathrm{SL} / \mathrm{TL} / \mathrm{B} .02 / \mathrm{Add} /$ Ampli \\
\hline & $01 / \mathrm{SL} / \mathrm{TL} / \mathrm{B} .03 / \mathrm{Add} /$ Ampli \\
\hline & $01 / \mathrm{SL} / \mathrm{TL} / \mathrm{B} .04 / \mathrm{Add} /$ Ampli \\
\hline & $01 / \mathrm{SL} / \mathrm{TL} / \mathrm{B} .05 / \mathrm{Add} /$ Ampli \\
\hline & $01 / \mathrm{SL} / \mathrm{TL} / \mathrm{B} .06 / \mathrm{Add} /$ Ampli \\
\hline & $01 / \mathrm{SL} / \mathrm{TL} / \mathrm{B} .07 / \mathrm{Add} /$ Ampli \\
\hline
\end{tabular}

\section{Classifiers}

It is a convenient tool for building meaningful redundancy into an overloaded text, especially in languages which use some terms to identify proper names and borrowed terms. One of the data which use classifiers technique is:

\section{Datum 01/SL/TL/C.01/Add/Class}

SL: Pergamum (p.51)

TL: Kota Pergamum (p.47)

The datum above shows that the adaptors add the word 'kota' before 'Pergamum'. It is to clear that 'Pergamum' is a city.

The data which use classifiers techniques are 2 data as in the table follows:

Table 4 : Classifiers

\begin{tabular}{|l|c|}
\hline No & Code \\
\hline & 01/SL/TL/C.01/Add/Class \\
\hline & $01 /$ SL/TL/C.02/Add/Class \\
\hline
\end{tabular}

From the data above, it can be concluded that the data distribution of addition technique as follows: the total data in this technique are 12 data (16,4\% from the whole data). The subtypes of addition technique are obligatory specifications ( 3 data or $4,1 \%$ ), amplifications ( 7 data or $9,6 \%$ ), and classifiers (2 data or $2,7 \%$ ). 


\section{Subtraction}

Subtraction eliminates or reduces unnecessary repetition to avoid ambiguity. Though subtraction eliminates or reduces the word or phrase or even the entire text, it is expected that it does not eliminate or reduce the message. It makes target language more effective so the people in target language can get the message easily.

The researcher finds 6 data which use subtractions technique. They are categorized into 2 subtypes as follow:

\section{Conjunctions}

In this type, subtractions conducted by deleting conjunction. There are 3 data which use conjunctions technique, one of the datum is:

Datum 02/SL/TL/A.01/Sub/Conj

SL: to His God and Father (p.22)

TL: bagi Allah Bapa-Nya (p.20)

The adaptors eliminate conjunction 'and' because between 'God' and 'Father' there is a link co-ordinate or relationship. They want to clarify that 'God' and 'Father' are not two persons but only one.

Datum 02/SL/TL/A.02/Sub/Conj

SL: Then I looked, and I heard (p.140)

TL: Lalu aku melihat, aku mendengar (p.140)

In this data, the adaptors delete the conjunction 'and'. It because between the first and the second event are occurred in one time.

The data which use conjunctions technique are as follow:

Table 5: Conjunctions

\begin{tabular}{|l|l|}
\hline \multirow{2}{*}{ No } & Code \\
\hline & 02/SL/TL/A.01/Sub/Conj \\
\hline & $02 /$ SL/TL/A.02/Sub/Conj \\
\hline & $02 /$ SL/TL/A.03/Sub/Conj \\
\hline
\end{tabular}

\section{Formulae}

When a word has no equivalent meaning in another language, it does not mean that all of words have to be translated from source language into target language. If a word is regarded 
meaningless, it is better to eliminate it. The adaptors eliminate the word which is regarded meaningless in target language.

Datum 02/SL/TL/B.01/Sub/For

SL: He who reads aloud (p. 16)

TL: Ia yang membacakan (p. 14)

From the data above the verb 'aloud' is eliminated. Although, 'aloud' is not translated, it does not reduce the message. 'Aloud' indicates an adverb.

Datum 02/SL/TL/B.02/Sub/For

SL: You have the name of being alive, and you are dead (p.66)

TL: Engkau dikatakan hidup, padahal engkau mati (p.63)

The adaptors eliminate phrase 'the name', because it was meaningless.

Table 6: Formulae

\begin{tabular}{|l|c|}
\hline No & Code \\
\hline & $02 /$ SL/TL/B.01/Sub/For \\
\hline & $02 /$ SL/TL/B.02/Sub/For \\
\hline & $02 /$ SL/TL/B.03/Sub/For \\
\hline
\end{tabular}

From the data above, it can be concluded that the data distribution of subtraction technique as follows: the total data in this technique are 6 data $(8,2 \%$ from the whole data). The subtypes of subtraction technique are conjunction ( 3 data or $4,1 \%$ ), and formulae ( 3 data or $4,1 \%$ ). Both of the types have the same number of data.

\section{Alterations}

Alterations come from the simplest problem of correspondence in sounds to the most complicated adjustment in idiomatic phrases (Nida, 1964:233). It is because the changes occur in the form of sound until the semantic problems. In this research, alterations technique is mostly used by the adaptors. There are 55 data which are divided into 7 subtypes as follows:

\section{Sounds}

The change of the word is caused by transliteration when a new word is introduced from source language. It is conducted by the adaptors to adapt the utterance in target language. The examples of the data are:

Datum 03/SL/TL/A.01/Alt/Sou

SL: Jesus Christ (p.19) 
TL: Yesus Kristus (p.18)

From the data above, alteration of sounds is conducted by the adaptors. It is to adjust the name Jesus Christ into Yesus Kristus in order to be natural.

Datum 03/SL/TL/A.02/Alt/Sou

SL: Ephesus (p.37)

TL: Efesus (p.33)

The word 'Ephesus' is rendered as 'Efesus' to adapt the utterance in target language.

There are 15 data which use sounds technique with the code as follow:

Table 7: Sounds

\begin{tabular}{|c|c|}
\hline No & Code \\
\hline & 03/SL/TL/A.01/Alt/Sou \\
\hline & 03/SL/TL/A.02/Alt/Sou \\
\hline & 03/SL/TL/A.03/Alt/Sou \\
\hline & 03/SL/TL/A.04/Alt/Sou \\
\hline & 03/SL/TL/A.05/Alt/Sou \\
\hline & 03/SL/TL/A.06/Alt/Sou \\
\hline & 03/SL/TL/A.07/Alt/Sou \\
\hline & 03/SL/TL/A.08/Alt/Sou \\
\hline & 03/SL/TL/A.09/Alt/Sou \\
\hline & 03/SL/TL/A.10/Alt/Sou \\
\hline & 03/SL/TL/A.11/Alt/Sou \\
\hline & 03/SL/TL/A.12/Alt/Sou \\
\hline & 03/SL/TL/A.13/Alt/Sou \\
\hline & 03/SL/TL/A.14/Alt/Sou \\
\hline & 03/SL/TL/A.15/Alt/Sou \\
\hline
\end{tabular}




\section{Categories}

Alterations of categories include not only shifts of forms within categories, but also the usage of expressions which have no corresponding function in the source language.

A singular expression may be altered to a plural, a past tense may be changed to a future, and shifts from active to passive or passive to active also involve alterations of categories. The researcher finds 6 data which use categories technique. The examples of the data are:

Datum 03/SL/TL/B.01/Alt/Ctgrs

SL: White Garments (p.89)

TL: Pakaian Putih (p.85)

In this datum, plural form in SL 'white garments' is rendered as singular form in TL.

Datum 03/SL/TL/B.03/Alt/Ctgrs

SL: He opened the shaft of the bottomless pit. (p.143)

TL: Maka dibukanyalah pintu lubang jurang maut itu. (p.144)

From the datum above, active sentence in SL is translated into passive sentence in TL. The active verb 'opened' is translated into passive verb 'dibukanyalah'.

\section{Datum 03/SL/TL/B.04/Alt/Ctgrs}

SL: After this I looked, and the temple of the tent of witness in heaven was opened,.... (p.226)

TL: Kemudian dari pada itu aku melihat orang membuka Bait Suci - kemah kesaksian - di sorga. (p.230)

In this datum, the adaptors translated passive verb 'was opened' into active verb 'membuka'.

The $6^{\text {th }}$ data which use categories techniques are as follows:

Table 8: Categories

\begin{tabular}{|l|c|}
\hline \multirow{2}{*}{ No } & Code \\
\hline & $03 / \mathrm{SL} / \mathrm{TL} / \mathrm{B} .01 /$ Alt/Ctgrs \\
\hline & $03 / \mathrm{SL} / \mathrm{TL} / \mathrm{B} .02 /$ Alt/Ctgrs \\
\hline & $03 / \mathrm{SL} / \mathrm{TL} / \mathrm{B} .03 / \mathrm{Alt} / \mathrm{Ctgrs}$ \\
\hline & $03 / \mathrm{SL} / \mathrm{TL} / \mathrm{B} .04 /$ Alt/Ctgrs \\
\hline & $03 / \mathrm{SL} / \mathrm{TL} / \mathrm{B} .05 /$ Alt/Ctgrs \\
\hline & $03 / \mathrm{SL} / \mathrm{TL} / \mathrm{B} .06 /$ Alt/Ctgrs \\
\hline
\end{tabular}

\section{Word classes}


In this type, the shifts occur from one class of word to another. The researcher finds 2 data which use this technique. The examples of the data are:

Datum 03/SL/TL/C.01/Alt/WC

SL: For the Lamb in the midst of the throne will be their shepherd. (p.131)

TL: Sebab Anak Domba yang di tengah-tengah takhta itu akan menggembalakan mereka. (p.131)

In this data, alterations occur by changing noun phrase 'their shepherd' in SL into verb 'menggembalakan mereka' in TL.

The data with the code as follows:

Table 9: Word classes

\begin{tabular}{|l|c|}
\hline No & Code \\
\hline & 03/SL/TL/C.01/Alt/WC \\
\hline & $03 /$ SL/TL/C.02/Alt/WC \\
\hline
\end{tabular}

\section{Order}

In this type of alterations, the order of words is shifted. There are certain situations in which the shifts of order may not seem so vital, but in which they are nevertheless important, if the translation is to be natural. The researcher finds 6 data, one of the data is:

Datum 03/SL/TL/D.01/Alt/Ord

SL: Write what you see in a book. (p.29)

TL: Apa yang engkau lihat, tuliskanlah di dalam sebuah kitab. (p.26)

In this datum, there is a shift of order between SL and TL. In SL, vocative expression is placed at the beginning of the sentence, whereas in TL, it is placed in middle of the sentence.

The data which use order technique are 6 data, they are:

Table 10: Order

\begin{tabular}{|l|c|}
\hline No & Code \\
\hline & 03/SL/TL/D.01/Alt/Ord \\
\hline & 03/SL/TL/D.02/Alt/Ord \\
\hline
\end{tabular}




\begin{tabular}{|l|c|}
\hline & 03/SL/TL/D.03/Alt/Ord \\
\hline & $03 /$ SL/TL/D.04/Alt/Ord \\
\hline & $03 /$ SL/TL/D.05/Alt/Ord \\
\hline & $03 /$ SL/TL/D.06/Alt/Ord \\
\hline
\end{tabular}

\section{Clause and sentence structure}

In this type, the adaptors changed indirect sentence into direct sentence. The researcher found 1 datum:

\section{Datum 03/SL/TL/E.01/Alt/CSS}

SL: and swore by Him who lives forever and ever, who created heaven and what is in it, the earth and what is in it, and the sea and what is in it, that there should be no more delay. (p.159)

TL: dan ia bersumpah demi Dia yang hidup sampai selama-lamanya, yang telah menciptakan langit dan segala isinya, dan bumi dan segala isinya, dan laut dan segala isinya, katanya: "Tidak akan ada penundaan lagi!" (p.160)

From the datum above, the adaptors change indirect sentence in SL into direct sentence in TL.

4.1.1.1 Semantic problems involving single word

The translator is often forced by semantic structure of the receptor language to select an appropriate term because there is no equivalent term in target language. In this case, the adaptors select the word which has the similar meaning in target language. The examples of the data are:

\section{Datum 03/SL/TL/F.01/Alt/SPISW}

SL: The seven churches (p.18)

\section{TL: Ketujuh jemaat (p.16)}

From the data, 'churches' is not adapted into 'gereja' in Indonesia, because there is a more meaningful equivalent word, i.e. 'jemaat'. The adaptors decide to choose the word 'jemaat' to clarify that 'churches' here is not a real churches building but a community of people.

\section{Datum 03/SL/TL/F.02/Alt/SPISW}

\section{SL: Seven golden lampstands (p.29)}

TL: Tujuh kaki dian dari emas (p.26)

In this data, 'lampstands' is adapted into 'kaki dian'. The adaptors choose 'dian' as rendered of 'lamp' because it is appropriated to the culture of target language. Actually, 'dian' comes from Javanese but it has applied into Indonesia.

There are 19 data which are found by the researcher, they are in the table below: 
Table 11: Semantic problems involving single word

\begin{tabular}{|c|c|}
\hline No & Code \\
\hline & 03/SL/TL/F.01/Alt/SPISW \\
\hline & 03/SL/TL/F.02/Alt/SPISW \\
\hline & 03/SL/TL/F.03/Alt/SPISW \\
\hline & 03/SL/TL/F.04/Alt/SPISW \\
\hline & 03/SL/TL/F.05/Alt/SPISW \\
\hline & 03/SL/TL/F.06/Alt/SPISW \\
\hline & 03/SL/TL/F.07/Alt/SPISW \\
\hline & 03/SL/TL/F.08/Alt/SPISW \\
\hline & 03/SL/TL/F.09/Alt/SPISW \\
\hline & 03/SL/TL/F.10/Alt/SPISW \\
\hline & 03/SL/TL/F.11/Alt/SPISW \\
\hline & 03/SL/TL/F.12/Alt/SPISW \\
\hline & 03/SL/TL/F.13/Alt/SPISW \\
\hline & 03/SL/TL/F.14/Alt/SPISW \\
\hline & 03/SL/TL/F.15/Alt/SPISW \\
\hline & 03/SL/TL/F.16/Alt/SPISW \\
\hline & 03/SL/TL/F.17/Alt/SPISW \\
\hline & 03/SL/TL/F.18/Alt/SPISW \\
\hline & 03/SL/TL/F.19/Alt/SPISW \\
\hline
\end{tabular}




\section{Semantic problems involving exocentric expressions}

When there is no corresponding idiom in the target language, a slight adjustment in the source language expression may make it acceptable in the target language. The adaptors select the expression that is usually used in target language. The researcher finds 6 data, two of them are:

Datum 03/SL/TL/G.01/Alt/SPIEE

SL: And I will give him the morning star (p.64)

TL: Dan kepadanya akan Kukaruniakan bintang timur (p.60)

In this data, the adaptors translate the phrase 'the morning star' into 'bintang timur'. It refers to the planet Venus which appears in the east before the sun rises in the morning.

Datum 03/SL/TL/G.05/Alt/SPIEE

SL: It is these who follow the Lamb wherever He goes; these have been redeemed from mankind as first fruits for God and the Lamb. (p.208)

TL: Mereka adalah orang-orang yang mengikuti Anak Domba itu kemana saja Ia pergi. Mereka ditebus diantara manusia sebagai korban-korban sulung bagi Allah dan bagi Anak Domba itu. (p.211)

From this data, the adaptors translate the phrase 'first fruit' into 'korban-korban sulung'. In Hebrew agricultural society, the first part of the harvest of grain or fruit is dedicated to God, as a symbol that the whole harvest belonged to Him. Considering this matter, the adaptors are doing adaptation of culture in TL which has different way in giving a tribute to God. In culture of target language, it is conducted by giving a goat or cow that had been slain. So, the adaptors choose the phrase 'korban-korban sulung' as translated of 'first fruit'.

The data which use this technique to adjust the expressions are:

Table 12: Semantic problems involving exocentric expressions

\begin{tabular}{|c|c|}
\hline \multirow{2}{*}{ No } & Code \\
\hline & 03/SL/TL/G.01/Alt/SPIEE \\
\hline & $03 /$ SL/TL/G.02/Alt/SPIEE \\
\hline & $03 /$ SL/TL/G.03/Alt/SPIEE \\
\hline & 03/SL/TL/G.04/Alt/SPIEE \\
\hline & 03/SL/TL/G.05/Alt/SPIEE \\
\hline & 03/SL/TL/G.06/Alt/SPIEE \\
\hline
\end{tabular}


From the data above, it can be concluded that the data distribution of alteration technique as follows: the total data in this technique are 55 data $(74,2 \%$ from the whole data). The subtypes of alteration technique are sounds (15 data or 20,5\%), categories (6 data or 8,2 \%), word classes (2 data or $2,7 \%$ ), order (6 data or $8,2 \%$ ), clause and sentence structure (1 datum or 1,4\%), semantic problems involving single words (19 data or $26 \%$ ), and semantic problems involving exocentric expressions (6 data or $8,2 \%)$.

\section{Conclusion}

From the result and discussion about the types of techniques of adjustment and its classifications, some conclusions can be drawn as follows: After analyzing the Handbook on the Revelation to John and its translation, it is found that there are three types of techniques of adjustment offered by Nida (1964), i.e additions, subtractions, and alterations. Addition technique is divided into 3 subtypes, i.e. obligatory specifications ( 3 data or $4.1 \%$ ), amplifications (7 data or 9.6\%), and classifiers ( 2 data or 2.7\%). Subtraction technique is divided into 2 subtypes, i.e. conjunctions ( 3 data or $4.1 \%$ ) and formulae ( 3 data or $4.1 \%$ ). Alteration technique is divided into 7 subtypes, i.e. sounds (15 data or $20.5 \%$ ), categories (6 data or $8.2 \%$ ), word classes (2 data or $2.7 \%$ ), order (6 data or $8.2 \%$ ), clause and sentence structure (1 datum or 1.4\%), semantic problems involving single word (19 data or $26 \%$ ), and semantic problems involving exocentric expression (6 data or $8.2 \%$ ).

This research is expected to open wide opportunities and challenges to academicians, especially those in translation linguistics sphere to deepen their research and study, especially in translating the holy religious texts in order to be a new contribution to the translation fields.

\section{References}

Arikunto, Suharsimi. 2009, Manajemen Penelitian, Jakarta, PT. Rineka Cipta.

Bratcher, Robert G., and Howard A. Hatton. 1993, A Handbook on the Revelation to John, New York, United Bible Societies.

Creswell, John W. 2003, Research Design: Qualitative, Quantitative, and Mixed Method Approaches, $2^{\text {nd }}$ edition, USA, Sage Publications, Inc.

Hoed, Benny. 2006. Penerjemahan dan Kebudayaan. Jakarta : Pustaka Jaya

Lembaga Alkitab Indonesia. 2001, Alkitab dan Komunikas, . Jakarta, LAI.

Mildred, Larson. L. 1984, Meaning Based-Translation, Boston, University Press of America.

Nida, Eugene. A. 1964, Toward a Science of Translating: With Special Reference to Principles and Procedures Involved in Bible Translating, Netherland, E. J. Brill, Leiden.

Nida, Eugene. A and Charles R. Taber. 1982, The Theory and Practice of Translation, $2^{\text {nd }}$ edition, Netherland, E. J. Brill, Leiden.

Sutopo, H. B. 2006, Metodologi Penelitian Kualitatif: Dasar Teori dan Terapannya dalam Penelitian, Edisi Kedua, Surakarta, UNS Press.

Suryawinata, Zuchridin and Sugeng Hariyanto. 2003, Translation: Bahasa Teori dan Penuntun Praktis Menerjemahkan, Yogyakarta, Kanisius.

Tambur, Kareasi H. and Rosdianningsih Sinambela. 2000, Pedoman Penafsiran Alkitab: Wahyu kepada Yohanes, Jakarta, Lembaga Alkitab Indonesia. 